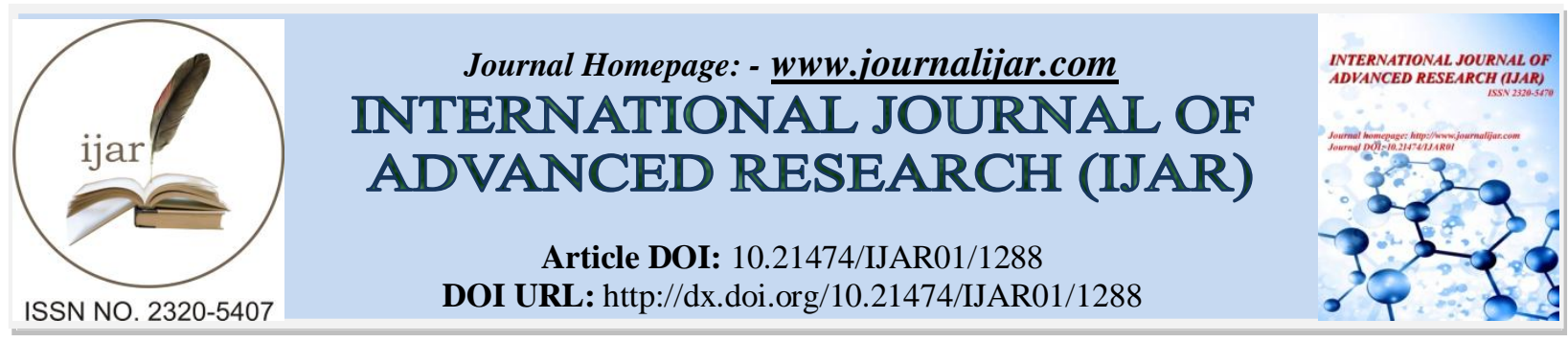

RESEARCH ARTICLE

\title{
ASSESSMENT OF PHYSICO-CHEMICAL PROPERTIES OF SURFACE WATER OF SHITALAKHYA RIVER NEAR POLASH, NARSINGDI, BANGLADESH.
}

Md. Abdul Mottalib ${ }^{1 *}$, A. N. M. Al-Razee ${ }^{2}$,Md. Nurul Abser ${ }^{3}$ and E.U.M. Aman ${ }^{2}$.

1. Institute of Leather Engineering and Technology, University of Dhaka, Dhaka-1209, Bangladesh.

2. Department of Analytical Chemistry and Environmental Science, Central Training Institute for Chemical Industries, Polash, Narsingdi-1611, Bangladesh.

3. Department of Chemistry, Jahagirnagar University, Savar, Dhaka, Bangladesh.

\section{Manuscript Info}

(..........................

Manuscript History

Received: 15 June 2016

Final Accepted: 16 July 2016

Published: August 2016

Key words:-

Physicochemical parameters,

Shitalakhya, effluent, Phosphate, COD,

Pollution.

\section{Abstract}

This study was carried out to examine the physico-chemical properties of the surface water of Shitalakhya River. Total thirty samples were collected from Polash-Ghorashal area in Narsingdi, Bangladesh and were analyzed for physico-chemical properties such as Temperature, $\mathrm{pH}, \mathrm{EC}$, Total Alkalinity, P-Alkalinity, DO, $\mathrm{BOD}_{5}, \mathrm{COD}, \mathrm{NH}_{3}-\mathrm{N}$, $\mathrm{NO}_{3}-\mathrm{N} \& \mathrm{SiO}_{2}$ to monitor the level of water quality of the River. Obtained results of the present study shows that most of the parameters exceed the maximum permissible limit in pre-monsoon and dry season. Ammonia was found to be the major pollutant of the River. Overall of the seasons $\mathrm{NH}_{3}-\mathrm{N}$ and $\mathrm{BOD}_{5}$ exceeded the allowable limit for aquatic life and the highest concentration of $\mathrm{NH}_{3}-\mathrm{N}$ $(342.99 \mathrm{mg} / \mathrm{L})$ was recorded along the River in pre-monsoon near at the point source of UFFL. Among the thirty samples, seventeen samples showed P-alkalinity probably due to hydroxide alkalinity. In pre-monsoon the DO value (2.59-3.82 mg/L) was found to be stressful for aquatic life though the value changes in winter season when it became highest $(6.6-5.86 \mathrm{mg} / \mathrm{L})$. From the statistical point of view temperature, $\mathrm{pH}$, alkalinity, $\mathrm{EC}, \mathrm{COD}, \mathrm{BOD}_{5}$, Ammonia- $\mathrm{N}, \mathrm{NO}_{3}-\mathrm{N}$ and $\mathrm{SiO}_{2}$ are positively correlated to each other while with $\mathrm{DO}$, most of the parameters are negatively correlated. The results reflect the poor effluent quality generated by Urea Fertilizer Factory (UFF) and indicates that the water of Shitalakhya River is not safe for drinking purposes, fisheries, recreational activities and various industrial uses particularly in Winter, Dry and Pre-monsoon seasons of the year.

Copy Right, IJAR, 2016,. All rights reserved.

\section{Introduction:-}

Surface waters are the most vulnerable to pollution due to their easy accessibility for disposal of waste waters. And in the midst of densely populated regions along the banks of the Shitalakhya and Buriganga River [1] large number of industries are situated. Shitalakhya River generates from old Brahmaputra at Tok of greater Mymensingh and flows through the red hard soil of Gazipur, Kaliganj, Narayanganj before it meets Meghna River at Kolagachia of 
Monshiganj. The Shitalakhya River is the major source of drinking water for the ever-expanding pollution of Dhaka city so the Dhaka Metropolitan Development Program has suggested to initiate environmental protection measures to prevent pollution of Shitalakhya River [2]. The River receives effluents from five jute mills, two fertilizer factories, one sugar mill, one cement industry, one textile industry, one dairy plant, two food processing industry, one hardboard mill, one paper mill and one thermal power plant within $13 \mathrm{~km}$ range of its flow in Ghorashal region. Among these industries, Polash Urea Fertilizer Factory, Urea Fertilizer Factory and Ghroshal Thermal power plant are considered as the KPI (key Point Installation). In industry, surface water is used for cooling, process, steam generation, safety and other miscellaneous purposes. The average consumption of surface water by Polash Urea Fertilizer Factory, Urea Fertilizer Factory and Ghroshal thermal power plant are 15600, 28800 and 28,80,000 t/d respectively from Shitalakhya River at polash region.

As far we know, there are very few published reports on the physicochemical parameters of surface water of Shitalakhya River [3-4]. The objective of the present study was to investigate the impact of Fertilizer Factories effluent on the river water and thus to provide an updated report on the state of water quality of the Shitalakhya River. Due to the industrial pollutants, sometimes died fish was found to float on the surface water of the River in the vicinity of Urea Fertilizer Factory that had been recorded [5]. Thus, it is important to determine the intensity of pollution by inventorying the physicochemical parameters and their spatial and temporal variation in water of Shitalakhya River. This study represents the level of water quality parameters such as Temperature, $\mathrm{pH}$, Total alkalinity, P-alkalinity, Conductivity, $\mathrm{COD}, \mathrm{BOD}_{5}, \mathrm{DO}, \mathrm{NH}_{3}-\mathrm{N}, \mathrm{NO}_{3}-\mathrm{N}$ and $\mathrm{SiO}_{2}$ in surface water of Shitalakhya River at Polash region.

\section{Materials and methods:-}

\section{Study area:-}

The study was conducted near the effluent channels from two Fertilizer industries - the Urea Fertilizer Factory (UFF) and Polash Urea Fertilizer Factory (PUFF) situated on the bank of Shitalakhya River at Polash region $9 \mathrm{~km}$ upstream from Ghorashal Bridge. The map of Polash is shown in fig $\mathbf{1 .}$

\section{Sampling Area:-}

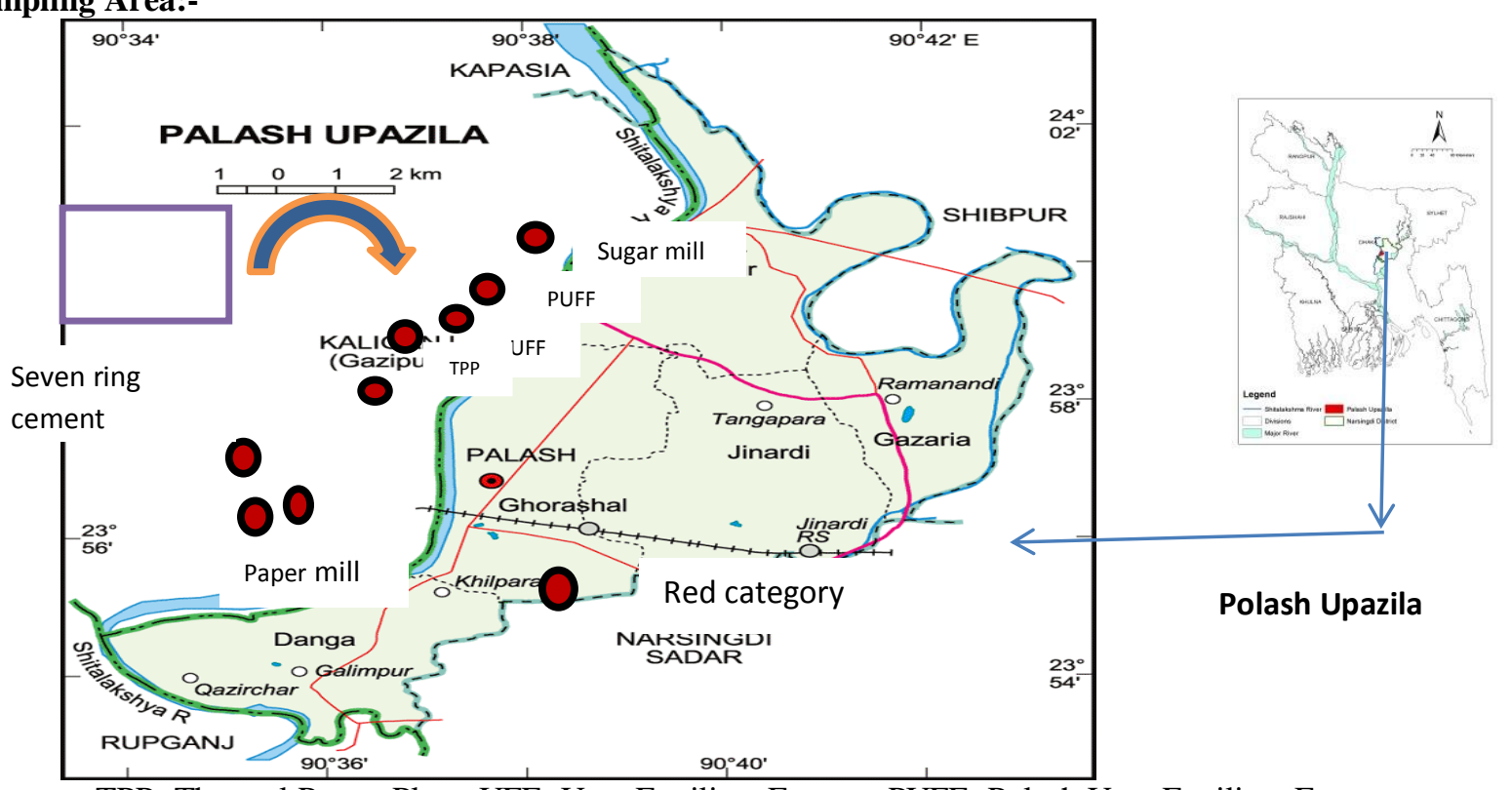

TPP- Thermal Power Plant, UFF- Urea Fertilizer Factory, PUFF- Polash Urea Fertilizer Factory.

Fig 1a:- Map of Polash. 
Sampling Strategy of Surface Water in Shitalakhya River near Fertilizer Factories.

E

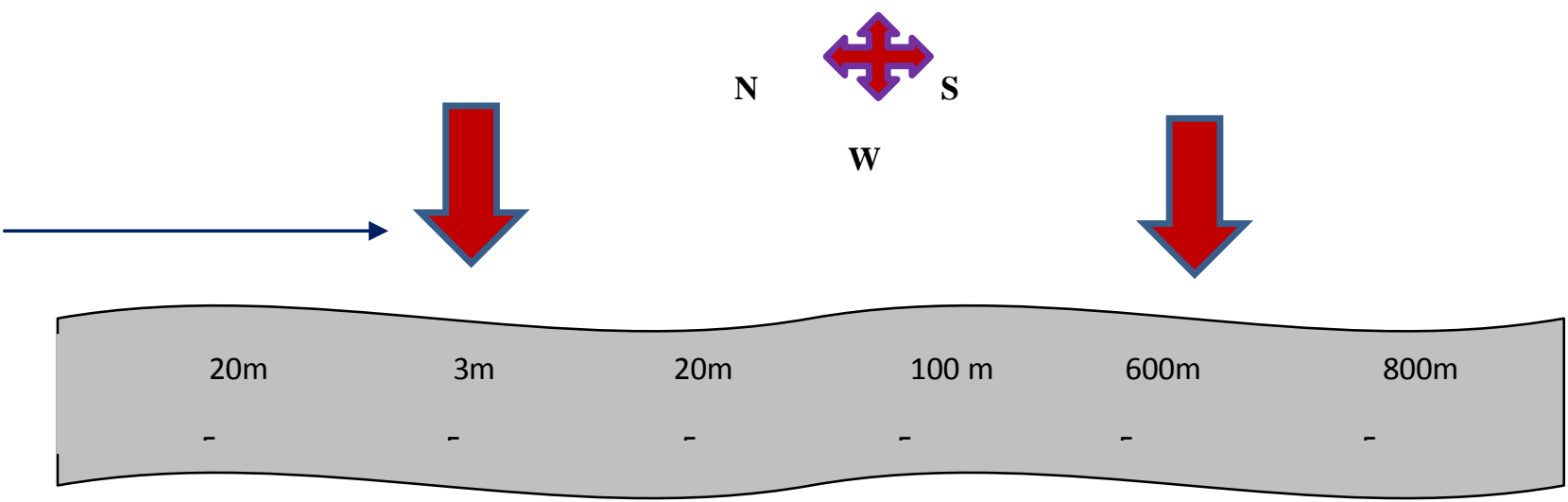

Fig 1b:- Sampling points at different distances of Shitalakhya River from the point source of UFF.

Generally the industries discharge high concentration ammonia rich effluents into lagoon and other effluents through point source into the Shitalakhya River.

\section{Sampling Locations \& Sample Collection:-}

Sampling was carried out from December 2010 to October 2011 in five seasons like December-January for winter, February for dry, March for pre-monsoon, June for monsoon and October for post monsoon. Six samples were taken for each season and each parameter. All together thirty samples were collected and analyzed. The sampling points are shown in fig 1(b). In the pre-monsoon and dry season the sampling was carried out during high tide. Among the six sampling points, two $\left(\mathrm{F}_{\mathrm{SW} 2} \& \mathrm{~F}_{\mathrm{SW} 5}\right)$ are respectively located close to the point source of Urea Fertilizer Factory (UFF) and Polash Urea Fertilizer Factory (PUFF). $\mathrm{F}_{\mathrm{Sw} 1}$ is located 20 meter upstream from the point source of UFF. The other sample points such as $\mathrm{F}_{\mathrm{SW}_{3}}, \mathrm{~F}_{\mathrm{SW} 4}, \mathrm{~F}_{\mathrm{Sw} 5}, \mathrm{~F}_{\mathrm{Sw} 6}$ are located $20 \mathrm{~m}, 100 \mathrm{~m}, 600 \mathrm{~m}, 800 \mathrm{~m}$ downstream from the point source of UFF respectively (fig. 1b). An engine boat was used for traveling into the River and samples were collected from a depth of about $20-25 \mathrm{~cm}$ below water surface. Two liter polypropylene bottles were used for water sample collection. Before taking final water samples, the bottles were rinsed three times with the water to be collected.

\section{Results and Discussion:-}

The collected samples were analyzed for the physico-chemical properties like Temperature, $\mathrm{pH}$, Total alkalinity, Palkalinity, EC, DO, $\mathrm{BOD}_{5}, \mathrm{COD}, \mathrm{NH}_{3}-\mathrm{N}, \mathrm{NO}_{3}-\mathrm{N}$ and $\mathrm{SiO}_{2}$. The temperature, $\mathrm{pH}$ and conductivity of water samples were measured immediately after collection at spot area [6]. Standard methods [7], [8], [9] and [10] were adapted for laboratory chemical analysis for the water quality parameters. Modified winkled method was used for the determination of dissolved oxygen. The results of different parameters are shown in Fig. 2. 
Graphical presentation of parameters:-

Figure 2 a:- Graphical presentation of physico-chemical parameters.
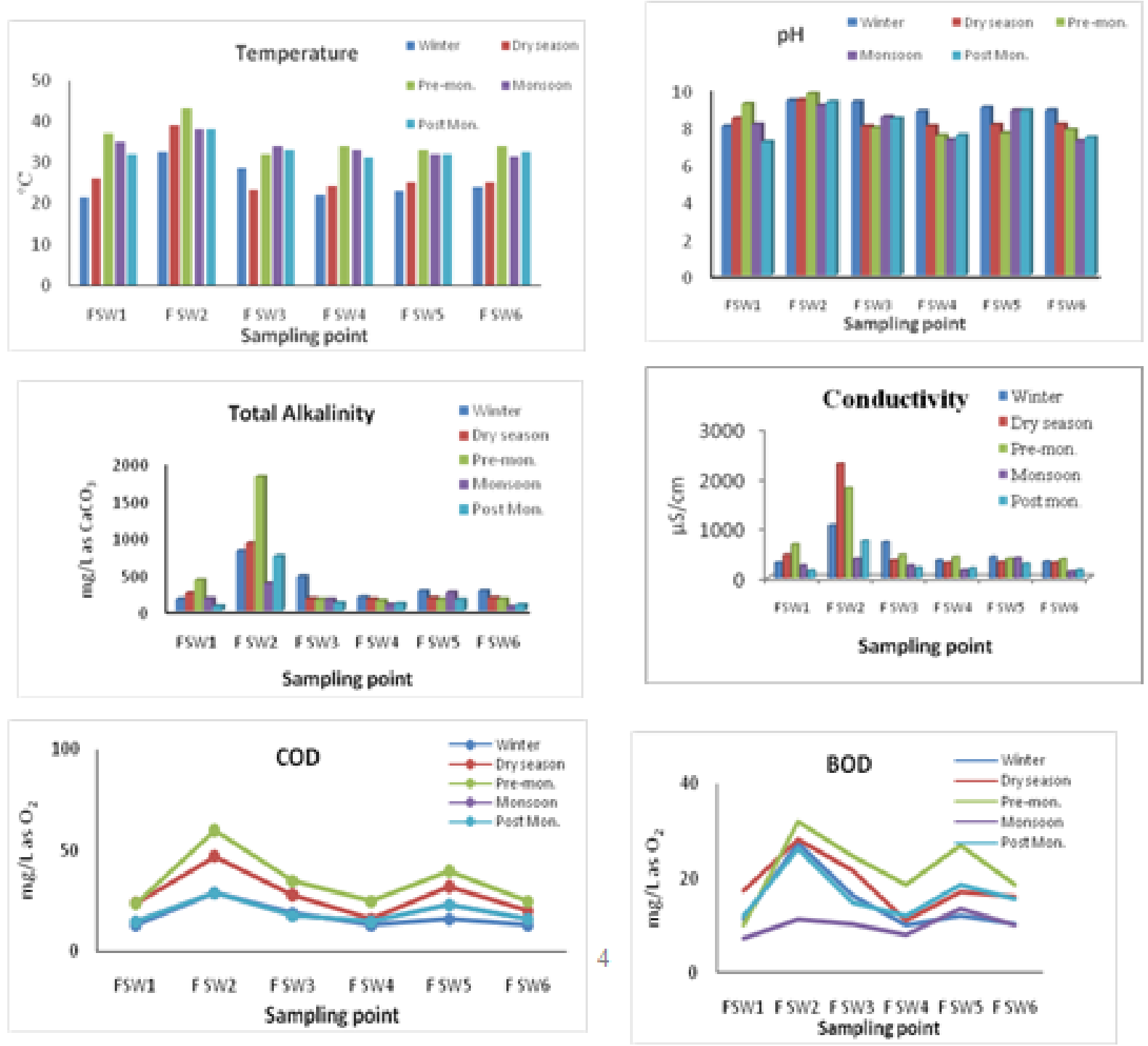
Figure 2 b:- Graphical presentation of physico-chemical parameters.
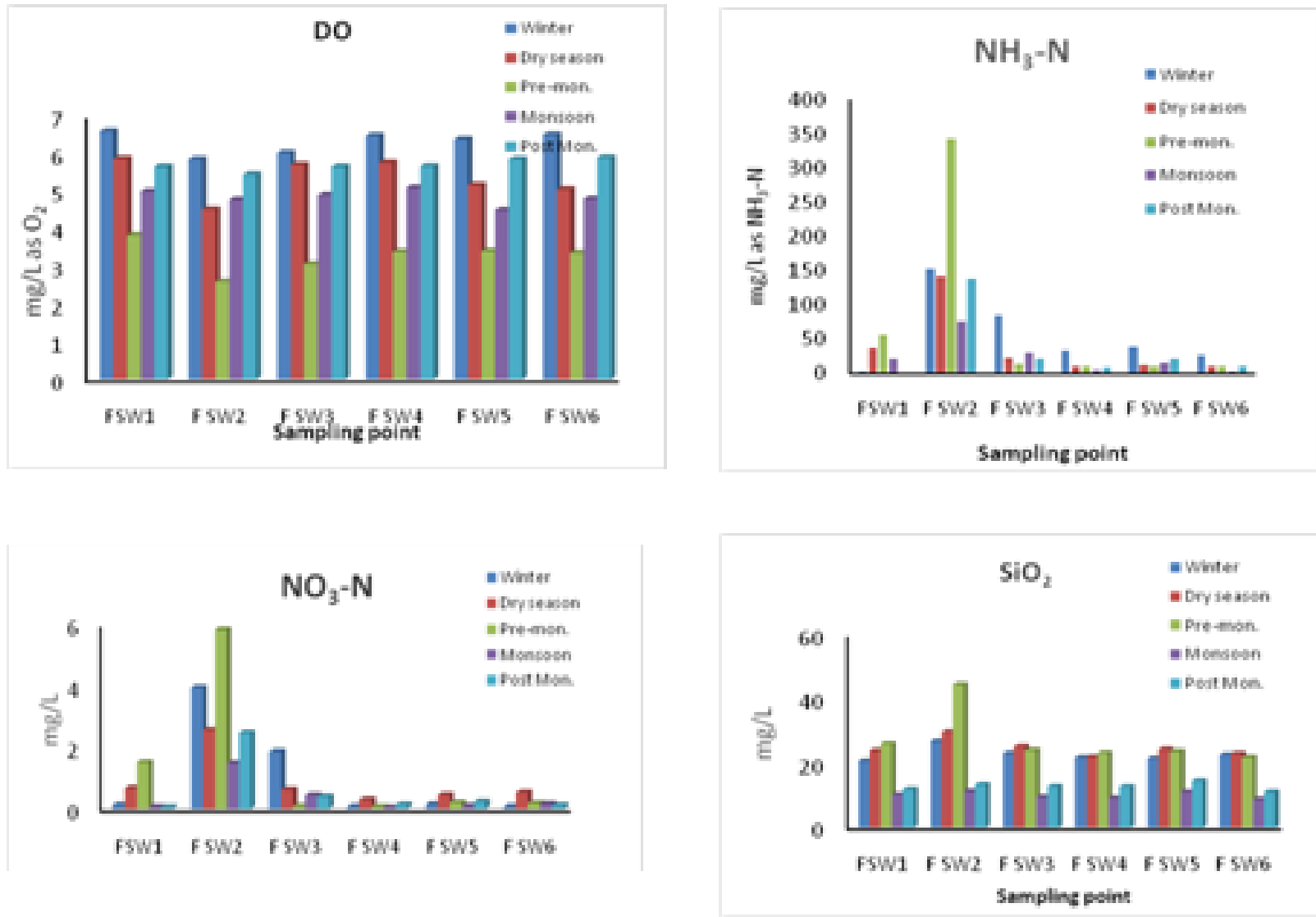

Statistical analysis:-

To establish the association among the parameters statistical analysis was performed by using the software MS Excel and Pearson's correlation (r) by SPSS (18.0 version).

Table 1: Correlation matrix among the parameters of Shitalakhya River $(\mathrm{N}=30)$.

\begin{tabular}{|l|c|c|c|c|c|c|c|c|c|c|}
\hline Parameter & Temperature & $\mathrm{pH}$ & Alkalinity & $\mathrm{EC}$ & $\mathrm{COD}$ & $\mathrm{BOD}_{5}$ & $\mathrm{DO}$ & $\mathrm{NH}_{3}-\mathrm{N}$ & $\mathrm{NO}_{3}-\mathrm{N}$ & $\mathrm{SiO}_{2}$ \\
\hline $\mathrm{pH}$ & .239 & 1 & & & & & & & & \\
\hline Alkalinity & $.525^{* *}$ & $.717^{* *}$ & 1 & & & & & & & \\
\hline $\mathrm{EC}$ & $.478^{* *}$ & $.651^{* *}$ & $.867^{* *}$ & 1 & & & & & & \\
\hline $\mathrm{COD}$ & $.440^{* *}$ & $.374^{*}$ & $.734^{* *}$ & $.774^{* *}$ & 1 & & & & & \\
\hline $\mathrm{BOD} 5$ & $.389^{* *}$ & .346 & $.649^{* *}$ & $.685^{* *}$ & $.907^{* *}$ & 1 & & & & \\
\hline $\mathrm{DO}$ & $-.662^{* *}$ & .036 & $-.331^{* *}$ & $-.332^{* *}$ & $-.604^{* *}$ & $-.452^{*}$ & 1 & & & \\
\hline $\mathrm{NH}_{3}-\mathrm{N}$ & $.541^{* *}$ & $.714^{* *}$ & $.990^{* *}$ & $.825^{* *}$ & $.698^{* *}$ & $.635^{* *}$ & -.297 & 1 & & \\
\hline $\mathrm{NO}_{3}-\mathrm{N}$ & $.530^{* *}$ & $.693^{* *}$ & $.959^{* *}$ & $.811^{* *}$ & $.687^{* *}$ & $.657^{* *}$ & -.277 & $.969^{* *}$ & 1 & \\
\hline $\mathrm{SiO}_{2}$ & .003 & $.458^{*}$ & $.671^{* *}$ & $.683^{* *}$ & $.782^{* *}$ & $.636^{* *}$ & -.336 & $.621^{* *}$ & $.618^{* *}$ & 1 \\
\hline
\end{tabular}

** Correlation is significant at the 0.01 level (2-tailed).

* Correlation is significant at the 0.05 level (2-tailed). N=No. of Samples

\section{Temperature:-}

Temperature of the study samples varied from $22.0^{\circ} \mathrm{C}$ to $43.0^{\circ} \mathrm{C}$ along the Shitalakhya River during the sampling period. Lowest temperature $22^{\circ} \mathrm{C}$ was recorded at 100 meters distance from the point source of UFFL in winter season while highest temperature $43^{\circ} \mathrm{C}$ was recorded at the outfalls of effluent of Urea Fertilizer Factory in pre- 
monsoon and the average temperature was also high in the pre-monsoon of the overall five seasons because huge amounts of turbine condensate were drained to the river. At the sampling point $\mathrm{F}_{\mathrm{SW} 2}$ situated near the point source of Urea Fertilizer Factory, the temperature ranged $32.5-43^{\circ} \mathrm{C}$ in five seasons that is most vulnerable. In a previous study Kabir [11] reported that the temperature of Shitalakhya River water at Narayanganj ranged from 19.7 to $32.2^{\circ} \mathrm{C}$. Azam et al. [12] studied the water quality parameters of the four river systems in the Sundarbans and found the temperature seasonally varied from $23.36^{\circ} \mathrm{C}$ to $30.3^{\circ} \mathrm{C}$ and Islam et al. [4] found the temperature of water ranged from 28 to $32^{\circ} \mathrm{C}$ in Shitalakhya River in June-July, 2007. The results of present investigation are higher than the findings of Azam et al. [12] and Islam et al. [4]. In very low temperature fish growth stops and in extremely high temperature fish will die [13]. From the statistical point of view temperature is significantly positive correlated with alkalinity, electrical conductivity, $\mathrm{BOD}_{5}, \mathrm{COD}, \mathrm{NH}_{3}-\mathrm{N}, \mathrm{NO}_{3}-\mathrm{N}$ while it has significantly negative correlation with DO. The obtained results indicate that the temperature of Shitalakhya River along the Fertilizer Factories area are within acceptable limit except the point source of UFFL where process steam condensate $(20 \mathrm{t} / \mathrm{h})$ from Urea plant, condensate drain from reflux drum $(10 \mathrm{t} / \mathrm{h})$ and boiler blow down $(08 \mathrm{t} / \mathrm{h})$ from ammonia plant process are continuously drained.

\title{
pH:-
}

The $\mathrm{pH}$ of water samples ranged from 7.15 to 9.75 . In the pre-monsoon the sampling was carried out during high tide so that sample points only $\mathrm{F}_{\mathrm{SW}_{1}}$ and $\mathrm{F}_{\mathrm{SW} 2}$ had high $\mathrm{pH}$ (9.1 to 9.75) that exceeded the allowable limit for fishing purpose. At the sampling station $\mathrm{F}_{\mathrm{sw} 2}, \mathrm{pH}$ value exceeded the limit for surface water standard of aquatic life [14] and WHO drinking water standard [15] in all the five seasons. The $\mathrm{pH}$ of water samples was mostly alkaline due to effluent containing $\mathrm{NH}_{3}$ from Urea Fertilizer Factory. The $\mathrm{pH}$ value (7.15-9.75) of the present study is higher than the previous study (7.5 to 8.4) that was performed by Islam et al. in June-July, 2007 in Shitalakhya River [4]. Therefore the $\mathrm{pH}$ of the Shitalakhya River water is not suitable for aquatic growth, the optimum ranges of $\mathrm{pH}$ for aquatic life is 6.8 to 9.0 [14].

\begin{abstract}
Alkalinity:-
Total alkalinity level varied from $50.4-1811.9 \mathrm{mg} / \mathrm{L}$ as $\mathrm{CaCO}_{3}$. The highest $(1811.9 \mathrm{mg} / \mathrm{L})$ and second highest $(998$ $\mathrm{mg} / \mathrm{L}$ ) level of alkalinity were recorded in the pre-monsoon and dry season respectively near the point source of UFFL. The P-alkalinity was also detected in this study. Over the all seasons P-alkalinity was high near the point source $\mathrm{F}_{\mathrm{sw} 2}$ of Urea Fertilizer Factory and highest was recorded $\left(535.7 \mathrm{mg} / \mathrm{L}\right.$ as $\left.\mathrm{CaCO}_{3}\right)$ in pre-monsoon due to outfall of ammonia containing effluent from the UFF and showed hydroxide alkalinity. For fishing purpose maximum recommended range of alkalinity is $200 \mathrm{mg} / \mathrm{L} \mathrm{[16].} \mathrm{Table} 1$ reveals that Alkalinity is significantly positively correlated with $\mathrm{pH}(\mathrm{r}=0.717), \mathrm{NH}_{3}-\mathrm{N}(\mathrm{r}=0.990), \mathrm{NO}_{3}(\mathrm{r}=0.959), \mathrm{EC}(\mathrm{r}=0.867), \mathrm{COD}(\mathrm{r}=0.734)$, BOD $(r=0.649)$ and $\mathrm{SiO}_{2}(r=0.671)$. The alkalinity observed in this study is higher than those found in Yamuna River of Agra city the range was $175-310 \mathrm{mg} / \mathrm{L}$ [17] and in the grab samples of effluents from nitrogenous fertilizer Factory at Kota the range was 50-350 mg/L [18].
\end{abstract}

\section{Electrical Conductivity (EC):-}

The results of conductivity of the current study were found ranged from 131.6 to $2292 \mu \mathrm{S} / \mathrm{cm}$ those are shown in fig. 2(a). The chart revealed that the conductivity of surface water exceeded the recommend value of FAO drinking water standard $(1000 \mu \mathrm{S} / \mathrm{cm})$ in winter, dry and pre-monsoon season at the outfall of UFFL's effluent. Maximum value was recorded in pre-monsoon $(2290 \mu \mathrm{S} / \mathrm{cm})$ due to discharge of Fertilizer Factories effluent, increased concentration of ions, less flow of water and increased evaporation. Minimum value $(131.6 \mu \mathrm{S} / \mathrm{cm})$ was recorded at the $800 \mathrm{~m}\left(\mathrm{~F}_{\mathrm{SW} 6}\right)$ downstream from the UFF point source in monsoon due to shut down of Fertilizer Factories at that period and dilution effect for high flow of water. Table 1 reveals that EC is significantly positively correlated with temperature $(\mathrm{r}=0.478), \mathrm{pH}(0.651)$, alkalinity $(\mathrm{r}=0.867)$, $\mathrm{COD}(\mathrm{r}=0.774), \mathrm{BOD}(\mathrm{r}=0.685), \mathrm{NH}_{3}-\mathrm{N}(\mathrm{r}=0.825)$, $\mathrm{NO}_{3}-\mathrm{N}(\mathrm{r}=0.811) \& \mathrm{SiO}_{2}(\mathrm{r}=0.683)$ and negatively correlated with $\mathrm{DO}(\mathrm{r}=-0.332)$. EC varied in the surface water in the order: pre-monsoon $>$ dry $>$ winter $>$ post monsoon $>$ monsoon. The values obtained in this study except the value of point sources in winter, dry and pre-monsoon are within the recommended value of Department of Environment (DoE) [19]. The EC values found in the present study is higher than those found in Ganges, Brahmaputra and confluence where the maximum and minimum electric conductivity values were $471 \mu \mathrm{S} / \mathrm{cm} \& 222$ $\mu \mathrm{S} / \mathrm{cm}$ and $195 \mu \mathrm{S} / \mathrm{cm} \& 120 \mu \mathrm{S} / \mathrm{cm}$ respectively [20]. 


\section{Chemical Oxygen Demand (COD):-}

Chemical Oxygen Demand (COD) varied from $10 \mathrm{mg} / \mathrm{L}$ to $60 \mathrm{mg} / \mathrm{L}$ along the Shitalakhya River in the five seasons. The highest $(60 \mathrm{mg} / \mathrm{L})$ and second highest $(40 \mathrm{mg} / \mathrm{L})$ value of COD were recorded at 3 to 4 meter distance from the point source of UFF and PUFF respectively in the pre-monsoon due to oil bearing effluents such as lube oil, seal oil from compressors and heavy duty pumps were drained to the River through point source and minimum was recorded $(10 \mathrm{mg} / \mathrm{L})$ in the 20 meter upstream from the point source of UFF in monsoon due to dilution effect and high flow of water in the River. Table 1 reveals that COD has significantly positive correlation with BOD $(r=$ 0.907), Alkalinity $(r=0.734), \mathrm{EC}(\mathrm{r}=0.774), \mathrm{SiO}_{2}(\mathrm{r}=0.782) \&$ temperature $(\mathrm{r}=0.440)$ and significantly negative correlation with DO $(\mathrm{r}=-0.604)$. Islam et al. [4] found COD range from $15-23 \mathrm{mg} / \mathrm{L}$ in Shitalakhya River. The COD values for monsoon (10 to $15 \mathrm{mg} / \mathrm{L})$ has a good concordance of the previous works of Islam et al. [4]. On the other hand another previous literature revealed that the maximum COD values of Ganges, Brahmaputra and confluence were $103 \mathrm{mg} / \mathrm{L}, 75 \mathrm{mg} / \mathrm{L} \& 102 \mathrm{mg} / \mathrm{L}$ and minimum values were $15 \mathrm{mg} / \mathrm{L}, 16 \mathrm{mg} / \mathrm{L} \& 13 \mathrm{mg} / \mathrm{L}$ [20]. Thus it indicates that the surface water in the studied area is relatively better with respect to COD compared to Ganges, Brahmaputra and confluence although does not meet the standard for drinking water.

\section{Biochemical Oxygen Demand $\left(\mathrm{BOD}_{5}\right)$ :-}

The values of Biochemical Oxygen Demand $\left(\mathrm{BOD}_{5}\right)$ of the present study samples varied from 7.2 to $32.0 \mathrm{mg} / \mathrm{L}$. The fig. 2(a) revealed that the BOD values $(10.2-32.0 \mathrm{mg} / \mathrm{L})$ of Shitalakhya River water in winter and pre-monsoon season were comparatively higher than the other seasons and the range of BOD (7.2- $13.6 \mathrm{mg} / \mathrm{L})$ was lowest in monsoon season. The maximum BOD value of Shitalakhya River water was recorded in the pre-monsoon season near the point source of UFF $(32.0 \mathrm{mg} / \mathrm{L})$. BOD $(\mathrm{r}=0.907)$ shows strong positive correlation with COD and also shows significantly positive correlation with Alkalinity $(\mathrm{r}=0.649), \mathrm{EC}(\mathrm{r}=0.685), \mathrm{NH}_{3}-\mathrm{N}(\mathrm{r}=0.635), \mathrm{NO}_{3}-\mathrm{N}(\mathrm{r}=$ $0.657), \mathrm{SiO}_{2}(\mathrm{r}=0.636) \&$ Temperature $(\mathrm{r}=0.389)$ and significantly negative correlation with $\mathrm{DO}(\mathrm{r}=-0.452)$. The temperature of the water can also contribute to high BOD levels for example warmer water usually will have a higher BOD value than colder water. The highest BOD was recorded for the river water adjacent to Urea Fertilizer Factories discharge point. The BOD values of all seasons were exceeded the permissible levels for aquatic life. The permissible limit for BOD for drinking water is $0.2 \mathrm{mg} / \mathrm{L}$, for recreation $3 \mathrm{mg} / \mathrm{L}$, for fish $6 \mathrm{mg} / \mathrm{L}$ and $10 \mathrm{mg} / \mathrm{L}$ for irrigation [19]. Another standards showed that BOD $<1 \mathrm{mg} / \mathrm{L}$ indicates pristine streams, $<5 \mathrm{mg} / \mathrm{L}$ unpolluted natural streams, $5-8 \mathrm{mg} / \mathrm{L}$ moderately polluted streams [21]. So the BOD values were not support for fish culture and irrigation activities and not suitable for drinking purpose. Islam et al. [4] found the BOD values ranged from 9$14 \mathrm{mg} / \mathrm{L}$ in Shitalakhya River whereas Hadiuzzaman et al. [22] found 11-16 mg/L BOD in Shitalakhya River and $22-54 \mathrm{mg} / \mathrm{L}$ in Balu river. The BOD values of present study nearly similar to the BOD values of Balu River and higher than the study carried out by Islam et al. [4].

\section{Dissolved oxygen (DO):-}

DO value of the current study samples varied from 2.59 to $6.60 \mathrm{mg} / \mathrm{L}$. DO values of the study samples found in winter, dry, pre-monsoon, monsoon and post-monsoon seasons are 5.85 to $6.6 \mathrm{mg} / \mathrm{L}, 5.86$ to $4.5 \mathrm{mg} / \mathrm{L}, 2.59$ to 3.82 $\mathrm{mg} / \mathrm{L}, 4.5$ to $5.1 \mathrm{mg} / \mathrm{L}, 5.44$ to $5.89 \mathrm{mg} / \mathrm{L}$ respectively. Effects of biodegradable waste discharge into a water body are largely determined by the oxygen balance of the system. It was observed that DO is comparatively higher in the winter and lower in pre-monsoon season. The lowest DO was recorded adjacent to Fertilizer Factories discharge point $\left(\mathrm{F}_{\mathrm{sw} 2}\right)$ due to the effluents containing process steam condensate during the Factories running. The solubility of DO depends on temperature and concentration of dissolved minerals in water. As the temperature increases the oxygen saturation decreases and an increase in the concentration of dissolved salts lessens the saturation concentration of oxygen [23]. Table 1 reveals that DO is significantly negative correlated with temperature $(\mathrm{r}=$ $0.662)$, COD (-0.604), BOD (-0.452), and insignificantly negative correlated with alkalinity (-0.331), EC (-0.332), ammonia nitrogen (-0.297), nitrate nitrogen $(-0.277)$ and silica (-0.336). The lowest DO was recorded $(2.59 \mathrm{mg} / \mathrm{L})$ near the point source of UFF in pre-monsoon and low flow of water was recorded at that point. Moreover, the data reveals that during the pre-monsoon season, the mean DO level slightly increased from 2.59 to $3.82 \mathrm{mg} / \mathrm{L}$ from upstream to the downstream of the river while in winter season its value increased from 5.86 to $6.6 \mathrm{mg} / \mathrm{L}$. The minimum DO value requires for healthy fish is 5 to $6 \mathrm{mg} / \mathrm{L}$, if this value decrease to $4.0-4.5 \mathrm{mg} / \mathrm{L}$, the water body is considered as heavily polluted [21]. The measured levels of DO never reached the acceptable level in any of the sampling stations in pre-monsoon. Its deficiency directly affects the ecosystem of a river water due to bioaccumulation and bio magnifications. 


\section{Ammonia Nitrogen $\left(\mathrm{NH}_{3}-\mathrm{N}\right)$ :-}

The amount of ammonia nitrogen varied from 1.52 to $342.99 \mathrm{mg} / \mathrm{L}$ along the River in the five seasons. The study revealed that the ammonia nitrogen also varied from 2.80 to $153.06 \mathrm{mg} / \mathrm{L}, 10.03$ to $142.87 \mathrm{mg} / \mathrm{L}, 9.95$ to 342.99 , 3.83 to $77.19 \mathrm{mg} / \mathrm{L}$ and 1.52 to $138.87 \mathrm{mg} / \mathrm{L}$ in winter, dry, pre-monsoon, monsoon and post monsoon season respectively. The highest concentration was recorded at the point source of Urea Fertilizer Factory $\left(\mathrm{F}_{\mathrm{sw} 2}\right)$ in premonsoon and lowest concentration was recorded at the $20 \mathrm{~m}$ upstream of UFF point source in post monsoon. It was observed that at the sampling point $\left(\mathrm{F}_{\mathrm{SW} 1}\right)$, ammonia nitrogen concentration was so low in post monsoon and winter season because the sampling was carried out during ebb and on the other hand sampling was carried out during high tide in pre-monsoon and dry season. The table 1 indicates that $\mathrm{NH}_{3}-\mathrm{N}$ shows strong positive correlation with temperature $(\mathrm{r}=0.541), \mathrm{pH}(\mathrm{r}=0.714)$, alkalinity $(\mathrm{r}=0.990), \mathrm{EC}(\mathrm{r}=0.825), \mathrm{NO}_{3}-\mathrm{N}(\mathrm{r}=0.969), \mathrm{SiO}_{2}(\mathrm{r}=0.621)$, $\mathrm{COD}(\mathrm{r}=0.698)$ and BOD $(\mathrm{r}=0.635)$ and insignificantly negative correlation with DO $(\mathrm{r}=-0.297)$. The concentration of ammonia-nitrogen at the point source of Urea Fertilizer Factory $\left(\mathrm{F}_{\mathrm{sw} 2}\right)$ was higher than the other points in all seasons. This value is higher than the acceptable level $(0.5 \mathrm{mg} / \mathrm{L})$ [24]. Urea Fertilizer Factory discharges its ammonia containing effluents near the sampling point $\mathrm{F}_{\mathrm{sw2} 2}$. Another contamination source might be the process condensate containing ammonia-cal nitrogen about $20 \mathrm{ppm}$ continuously drained from process condensate stripper tank at the rate of $20 \mathrm{t} / \mathrm{h}$ from urea plant are drained to the river through point source. The disposal of fertilizer industry effluents into nearby water resources poses a eminent danger especially in regard to maintenance of fish life. At $25^{\circ} \mathrm{C}$ temperature and $\mathrm{pH} 7.5$, maximum allowable limit of $\mathrm{NH}_{3}-\mathrm{N}$ for the protection of aquatic life is 0.89 $\mathrm{mg} / \mathrm{L}$ and the toxicity increases with $\mathrm{pH}$ and temperature [25].

\section{Nitrate $\left(\mathrm{NO}_{3}-\mathrm{N}\right)$ :-}

Nitrate concentration (expressed as $\mathrm{NO}_{3}-\mathrm{N}$ ) varied from 0.05 to $5.85 \mathrm{mg} / \mathrm{L}$ along the Shitalakhya River in five seasons. The highest concentration of $\mathrm{NO}_{3}-\mathrm{N}$ was observed $(5.85 \mathrm{mg} / \mathrm{L})$ near the point source of Urea Fertilizer Factory in pre-monsoon. The lowest concentration of $\mathrm{NO}_{3}-\mathrm{N}$ was observed $(0.05 \mathrm{mg} / \mathrm{L})$ in the monsoon at $100 \mathrm{~m}$ downstream from the point source of Urea Fertilizer Factory. Alam et al. [3] found $\mathrm{NO}_{3}-\mathrm{N}$ varied from 0.2 to 1.8 $\mathrm{mg} / \mathrm{L}$ in Shitalakhya River at Tarabo area in dry season while Ahmed et al. [1] found that $\mathrm{NO}_{3}{ }^{-}$load of Buriganga River water during rainy, dry and summer were $0.917 \pm 0.47,0.43 \pm 0.61$ and $0.68 \pm 0.14 \mathrm{mg} / \mathrm{L}$ respectively and that in Karnatoli River water were $0.45 \pm 0.32,1.16 \pm 0.40$ and $0.76 \pm 0.11 \mathrm{mg} / \mathrm{L}$ respectively. The chart reveals that at the point source of Urea Fertilizer Factory $\left(\mathrm{F}_{\mathrm{SW}_{2}}\right)$ concentration of $\mathrm{NO}_{3}-\mathrm{N}$ is abruptly high among the other points. That is due to the surface water containing ammonia $\left(\mathrm{NH}_{3}\right)$ which might be oxidized to nitrate $\left(\mathrm{NO}_{3}{ }^{-}\right)$catalyzed by two ubiquitous bacterial groups. The first reaction is oxidation of ammonium to nitrite by ammonium oxidizing bacteria (AOB) represented by the "Nitrosomonas" species. The second reaction is oxidation of nitrite $\left(\mathrm{NO}_{2}{ }^{-}\right)$to nitrate by nitrite-oxidizing bacteria (NOB), represented by the Nitrobacter species. Table 1 indicates that $\mathrm{NO}_{3}-\mathrm{N}$ shows the strong positive correlation with $\mathrm{NH}_{3}-\mathrm{N}(\mathrm{r}=0.969)$, Alkalinity $(\mathrm{r}=0.959), \mathrm{EC}(\mathrm{r}=0.811)$ \& also positive correlation with temperature, $\mathrm{pH}, \mathrm{COD}, \mathrm{BOD}$ and silica and negative correlation with $\mathrm{DO}(\mathrm{r}=-0.277)$. The present findings is also higher than the previous studies of Hadiuzzaman et al. [22] and reported that $\mathrm{NO}_{3}$ concentration in Balu River was 0.4 to $1.05 \mathrm{mg} / \mathrm{L}$ and Shitalakhya River was 0.1 to $3.5 \mathrm{mg} / \mathrm{L}$. However, Alam et al. [26] found that the concentration of $\mathrm{NO}_{3}{ }^{-}$in Buriganga River ranged from $8.0 \pm 0.5$ to $12.2 \pm 0.4 \mathrm{mg} / \mathrm{L}$ in rainy season and $8.0 \pm 0.5$ to $12.2 \pm 0.4 \mathrm{mg} / \mathrm{L}$ in dry season those are higher than the present study.

\section{Dissolved Silica $\left(\mathrm{SiO}_{2}\right)$ :-}

Silica concentration of the present study varied from 8.70 to $44.64 \mathrm{mg} / \mathrm{L}$. The highest concentration was recorded at point source of UFF in pre-monsoon due to high $\mathrm{pH}$ and high temperature because the presence of alkalinity encourages the formation of silicate ions and increases the solubility of silica and lowest was recorded in monsoon because slowness of the dissolution process of surface water. According to Pearson correlation matrix silica shows positive correlation with $\mathrm{pH}$, alkalinity, $\mathrm{EC}, \mathrm{COD}, \mathrm{BOD}_{5}$, ammonia and nitrate-nitrogen and also insignificantly positively correlated with temperature. Dissolved silica concentrations in river water depend on chemical weathering, hydrological cycle in the basin, biological process and dissolution on land and in water [27]. The concentration of silica was found in the increasing order of pre-monsoon > dry season > winter season > post monsoon > monsoon. Kennedy [28] explained that, in most cases, dilution and biological uptake by diatoms are the cause of low concentration of dissolved silica in river water. Adsorption of silica on suspended particles could also possibly remove silica from solution in the presence of electrolytes [29]. Silica is the most objectionable parameter in industrial water. Silica fouling and silica scaling of heat exchanger and equipment is a great problem. The problem of silica scaling is exacerbated in presence of low levels of polyvalent metal ions (i.e., aluminum, iron, calcium, magnesium, etc.) [30]. The maximum allowable limit for silica concentration in boiler feed water is 0.02 $\mathrm{mg} / \mathrm{L}$. 


\section{Conclusion:-}

From the present study it could be concluded that the overall pollution load was significantly high in pre-monsoon than in other seasons. The results showed that the quality of Shitalakhya River water was not acceptable for aquatic ecosystem perspectives because of the parameters such as DO was minimum in pre-monsoon and higher values of $\mathrm{BOD}_{5}$, and $\mathrm{NH}_{3}-\mathrm{N}$ in all seasons. The study had also concluded that some parameters such as temperature, $\mathrm{pH}$, conductivity of this river water were still acceptable in all seasons except the point source of Urea Fertilizer Factory. $\mathrm{NO}_{3}-\mathrm{N}$ values also was acceptable in all the seasons except at the point source area of UFF in pre-monsoon. The amount of silica was high in winter, dry season and in pre-monsoon. The analytical result shows that the river water adjacent to Urea Fertilizer Factories effluent discharge area is most vulnerable, the degree of contamination is gradually decreasing with increasing distance of point sources. The absence of fishes in the study area in winter, dry and pre-monsoon period may be due to the pollution by the effluents containing ammonia from the Urea Fertilizer Factory and Polash Urea Fertilizer Factory. Some fishes are found at monsoon may be due to migration of fish from catchments area. This study indicates that the water of the Shitalakhya River is being polluted from its surrounding point and non-point sources which include discharges from Fertilizer industries. If this situation deteriorates further, the river water might be lead to a physico-chemically dead for aquatic life. So, no permission should be given to install new industries along the bank of the Shitalakhya river without their effluent treatment plant as this river is used as a raw water source for drinking and industrial water supply. And there is the need for continual assessment of the level of pollution of this stream with a view to reduce the level of pollution via education and public enlightenment.

\section{Acknowledgments:-}

The authors wish to thank to Md. Hamidul Hoque, Analytical Chemistry \& Environmental Science Division, Training Institute for Chemical Industries (TICI) for the instrumental help.

\section{References:-}

1. Ahmed, M. K., M. Das, M. M. Islam, M. S. Akter, S. Islam and M. A. Al- Mansur, 2011. 'Phsico-chemical properties of tannery and textile effluents and surface water of river Buriganga and Karnatoli, Bangladesh', World Applied Sciences Journal, 12(2): 152-159.

2. Ershad K., 2009. 'A River in Distress. A weekly Publication of Daily Star. Issue 617, 13, March, 13: 8-15.

3. Alam, M. A., A.B.M. Badruzzaman and M. A. Ali, 2012. 'Assessment of water quality of the Shitalakhya river, Bangladesh', International Journal of Engineering and Technology, 2(6): 953-962.

4. Islam, M. H., M. M. Rahman and F. U. Ashraf, 2010. 'Assessment of water quality and impact of effluents from fertilizer factories to the Shitalakhya River'. International Journal of Water Resources and Environmental Engineering, 2(8): 208-221.

5. Post IEE report, Urea Fertilizer Factory Ltd. Ghorashal (UFFL) and Polash Urea Fertilizer Factory Ltd (PUFL). By: Trainee group of ADB Environmental Management Training Course. 1993.

6. APHA, Standard methods for the examination of water and wastewater. $20^{\text {th }}$ edn. American Public Health Association, Washington, DC, 1998.

7. ASTM, Standard test methods for acidity or alkalinity of water, 2003. Annual book of ASTM standards; 11(1), D 1067-02.

8. ASTM, Standard test methods for Dissolved Oxygen in water, Annual book of ASTM standards. 2003; 11(1), D 888-92:56-59.

9. ASTM, Standard test methods for Chemical Oxygen Demand in water, Annual book of ASTM standards. 2003; 11(1), D 1252:38-41.

10. ASTM, Standard test methods for Ammonia Nitrogen in water, Annual book of ASTM standards, 2003; 11(1), D 1426-98:148-149.

11. Kabir, K. M. H., 2011. 'Impact of textile effluent on water quality of the Shitalakhya river and suggested a mathematical model for assessment of environmental damages', Ph. D Thesis, p. 35.

12. Azam, K., M. A. Rouf, M. N. A Khanom and M. Shahriar, 2002. 'Water quality of the sunderban- seasonal and tidal variation in four river system', FMRT Discipline, Khulna University, Bangladesh; p. 27.

13. Rahaman, M. A. Water quality management. Hill Book Co. New York and London, 1992.

14. Trivedi P. R. and G. Raj, 1992. 'Encyclopedia of Environmental Sciences', 25: 144.

15. WHO, 1993. 'Guidelines for drinking water supply quantity' (2nd edn), 1, Recommendations. World Health Organization, Geneva, 180-181. 
16. Mowka, E., 1988. 'Understanding Factors that Affect pH \& Guide to Alkalinity and pH Control'. Sea scope. Aquarium Systems, p. 5.

17. Gupta, N., K. K. Yadav, V. Kumar and D. Singh, 2013. 'Assessment of Physicochemical Properties of Yamuna River in Agra City', International Journal of Chem Tech Research CODEN( USA), 5(1): 528-531.

18. Agarwal, S. K., 1996. 'Industrial Environment Assessment and Strategy'. APH Publishing Corporation, 5, Ansari Road, Darya Ganj, New Delhi11002, p. 386.

19. Department of Environment (DoE), Bangladesh, 1997. 'Environmental Conservation Rules', Schedule-3, Standards for water, p. 205.

20. Tareq, S. M., S. Y. Rikta, S. M. N. Islam and M. S. Sultana, 2013. 'Seasonal variations in water quality of the Ganges and Brahmaputra River, Bangladesh'. Jahangirnagar University Environmental Bulletin, 2: 71-82.

21. Eugen W., 2012. 'Application of Environmental Aquatic Chemistry', A practical guide, $3^{\text {rd }}$ Ed., 100 .

22. Hadiuzzaman M., A. B. Baki and S. M. Khan, 2006. 'Pollution status and trends in water quality of Shitalakhya and Balu River', The Journal of NOAMI, 23(2):1-22.

23. Gray, N. F., 1999. 'Factors determining the distribution of animals and plants in fresh waters'. John Wiley \& Sons Inc., 605 Third Avenue. New York, 67-68.

24. Rahman, M. A. and D. Al Bakri, 2010. 'A study on selected water quality parameters along the river Buriganga, Bangladesh', Iranica Journal of Energy \& Environment, 1(2): 81-92.

25. Environment Canada, Problem formulation for ammonia in the aquatic environment. Canadian Environmental Protection Act Priority Substances List 2. Version 5.0, 1997.

26. Alam, A. M. S., M. A. Islam, M. A. Rahman, M. N. Aalam, M. Siddique and M. A. Matin, 2003. 'Comparative study of toxic metals and nonmetal status in major river system of Bangladesh'. Dhaka University J. Sci., 51(2): 201-208.

27. Derry, L. A., C. Kurtz, K. Ziegler, O. A. Chadwick and E. F. Kelley, 2001. Plant phytolith source of dissolved silica in hawaiian streams from Ge/Si ratios. http://www.lpi.usra.edu/meetings/ gold2001/pdf/3805.pdf.

28. Kennedy, V. C., 1971. 'Silica variation in stream water with time and discharge', Adv. Chem. Ser., 106: 93-130.

29. Bien, G. S .N., D. E. Contois and W. H. Thomas, 1958. 'The removal of soluble silica from fresh water entering the sea', Geochim Cosmochim Acta., 14: 35-54.

30. Amjad, Z., R. W. Zuhl, Silica control in industrial water systems with a new polymeric dispersant. The Lubrizol Corporation. 2010. 